JoNEs, F. N. (1957). An analysis of individual differences in olfactory thresholds. American Journal of Psychology, 70, 227-232.

Moskowitz, H. R., Dravnieks, A., Cain, W. S., \& TURK, A. (1974). A standardized procedure for expressing odor intensity. Chemical Senses \& Flavor, 1, 235-237.

PunTer, P. H. (1983). Measurement of human olfactory thresholds for several groups of structurally related compounds. Chemical Senses, 7, 215-235.
SEmB, G. (1968). The detectability of the odor of butanol. Perception \& Psychophysics, 4, 335-340.

VAN Gemert, L. J., \& NetTenbreier, A. H. (1977). Compilation of odour threshold values in air and water. Zeist, The Netherlands: CIVO.

(Manuscript received February 15, 1986; revision accepted for publication March 30, 1986.)

\title{
Announcements
}

\author{
16th Annual Meeting \\ Society for Computers in Psychology
}

The 16th Annual Meeting of the Society for Computers in Psychology will be held at the Hyatt Regency Hotel, New Orleans, Louisiana, November 12, 1986. The meeting features papers on applications of computers to all areas of psychology-experimental, clinical, and educationalwith the emphasis on on-line, laboratory applications. Contact: Cyndi McDaniel, Psychology Department, Northern Kentucky University, Highland Heights, Kentucky 41076; (606) 572-5310.

\section{Call for Papers \\ Society for Computers in Psychology}

Papers and symposia are sought for the 16th Annual Meeting of the Society for Computers in Psychology, November 12, 1986, New Orleans, Louisiana. Deadline for papers: July 1, 1986. For more information, contact Cyndi McDaniel, Psychology Department, Northern Kentucky University, Highland Heights, Kentucky 41076; (606) 572-5310.

\section{Student Paper Competition Society for Computers in Psychology}

The Society for Computers in Psychology will continue to sponsor an award for the outstanding student paper submitted for presentation at the annual meeting. Although the primary emphasis of the meeting is the use of computers in on-line, experimental applications, student papers in any area of the application of computers to psychology are welcome. Papers may be theoretical, experimental, or applied in approach. Eligibility is open to (1) work done by a student currently enrolled in undergraduate or graduate courses or (2) work done as part of a course, thesis, or other student research by a person who has graduated in 1986. All papers submitted for the meeting (including multiply authored ones) in which the major contribution has been made by a student are eligible for the prize, and will be considered for presentation at the meeting and subsequent publication. The winning paper will be presented at the 1986 meeting, and the author will receive a complimentary 1-year membership in the meeting, a complimentary 1-year subscription to $\mathrm{Be}$ havior Research Methods, Instruments, \& Computers, and a \$50 cash prize. Deadline for papers: July $1,1986$.

Eligible papers should be submitted in quadruplicate. A cover sheet should include the author's name, mailing address, telephone number, and academic affiliation, a 50-word abstract, and a note stating that the paper is to be considered for the student award. These materials should be sent to: Cyndi McDaniel, Psychology Department, Northern Kentucky University, Highland Heights, Kentucky 41076; (606) 572-5310.

The winner of the 1985 competition was Brian Watts of New York University, whose paper is published in these Proceedings. 